Article

\title{
Synthesis, Crystal Structure, Luminescence, Electrochemical and Antimicrobial Properties of Bis(salamo)-Based Co(II) Complex
}

\author{
Li Wang, Jing Hao, Li-Xiang Zhai, Yang Zhang and Wen-Kui Dong * \\ School of Chemical and Biological Engineering, Lanzhou Jiaotong University, Lanzhou 730070, China; \\ wangli_78@126.com (L.W.); haojingmm@126.com (J.H.); zlxcgzx@163.com (L.-X.Z.); zhangy8124@163.com (Y.Z.) \\ * Correspondence: dongwk@126.com; Tel.: +86-931-493-8703 \\ Academic Editor: Shujun Zhang \\ Received: 5 September 2017; Accepted: 10 September 2017; Published: 12 September 2017
}

\begin{abstract}
A newly designed $\mathrm{Co}(\mathrm{II})$ complex, $\left[\mathrm{Co}_{3}(\mathrm{~L})(\mathrm{OAc})_{2}\left(\mathrm{CH}_{3} \mathrm{OH}\right)_{2}\right] \cdot \mathrm{CH}_{3} \mathrm{OH}$, by the reaction of a bis(salamo)-type tetraoxime ligand $\left(\mathrm{H}_{4} \mathrm{~L}\right)$ with $\mathrm{Co}(\mathrm{II})$ acetate tetrahydrate was synthesized and characterized by elemental analyses, IR, UV-vis spectra and single-crystal X-ray crystallography. The UV-vis titration experiment manifested that a trinuclear ( $\mathrm{L}: \mathrm{M}=1: 3)$ complex was formed. It is worth noting that the two terminal $\mathrm{Co}$ (II) (Co1 and Co3) atoms of the Co(II) complex have different coordination modes and geometries unreported earlier. Furthermore, through intermolecular interactions $(\mathrm{C}-\mathrm{H} \cdots \mathrm{O}, \mathrm{C}-\mathrm{H} \cdots \pi$ and $\mathrm{O}-\mathrm{H} \cdots \mathrm{O})$, a $2 \mathrm{D}$ layer-like network is constructed. In addition, the fluorescence behaviors, antimicrobial activities and electrochemical properties of $\mathrm{H}_{4} \mathrm{~L}$ and its Co(II) complex were investigated.
\end{abstract}

Keywords: complex; crystal structure; supramolecular interaction; luminescent study; cyclic voltammetry; antimicrobial activity

\section{Introduction}

$\mathrm{N}_{2} \mathrm{O}_{2}$ salen-type ligands and their analogues have been the focus of increasing attention because their metal complexes are used as catalysts of organic reactions [1-7], nonlinear optical materials [8-18], electrochemical fields [19-22], ion recognition [23-25], supramolecular architectures [26-37], biological fields [38-42], magnetic materials [43-46] and so forth. With respect to these complexes, phenoxo bridging plays a key role in assembling metal ions and salen-type ligands.

To date, a novel salen-type analogue, salamo, has been studied originally [47-54]. Salamo-type ligands and their metal complexes can resist the $\mathrm{C}=\mathrm{N}$ exchange reaction. They are also useful as a building block for larger supramolecules. In addition, if hydroxyl and naphthaleneol groups are introduced to the salamo-type ligands, a highly versatile coordination ability and preferable practical property are expected. Taking these factors into account, a new complex $\left[\mathrm{Co}_{3}(\mathrm{~L})(\mathrm{OAc})_{2}\left(\mathrm{CH}_{3} \mathrm{OH}\right)_{2}\right] \cdot \mathrm{CH}_{3} \mathrm{OH}$ containing naphthaleneol-based bis(salamo)-type tetraoxime ligand $\left(\mathrm{H}_{4} \mathrm{~L}\right)$ was synthesized and characterized by elemental analyses, IR, single-crystal X-ray crystallography and UV-vis titration. Meanwhile, the electrochemical properties of the $\mathrm{Co}(\mathrm{II})$ complex were investigated by cyclic voltammetry, and the fluorescent and antibacterial properties of $\mathrm{H}_{4} \mathrm{~L}$ and its $\mathrm{Co}$ (II) complex were also studied.

\section{Experimental}

Crystallographic data have been deposited with the Cambridge Crystallographic Data Centre (CCDC) as supplementary publication, No. CCDC 1572529. Copies of the data can be obtained free of charge on application to CCDC, 12 Union Road, Cambridge CB21EZ, UK (Telephone: +(44)-01223-762910; 
Fax: +44-1223-336033; E-mail: deposit@ccdc.cam.ac.uk). These data can be also obtained free of charge at www.ccdc.cam.Ac.uk/conts/retrieving.html.

\subsection{Materials and Methods}

2-Hydroxy-3-methoxybenzaldehyde (99\%), methyl trioctyl ammonium chloride (90\%), pyridinium chlorochromate (98\%) and boron tribromide (99.9\%) were purchased from Alfa Aesar (New York, NY, USA). Hydrobromic acid $33 \mathrm{wt} \%$ solution in acetic acid was purchased from J\&K Scientific Ltd. (Beijing, China). The other reagents and solvents were analytical grade reagents from Tianjin Chemical Reagent Factory (Tianjin, China) and used as received.

C, $\mathrm{H}$, and $\mathrm{N}$ analyses were obtained using a GmbH VarioEL V3.00 automatic elemental analysis instrument (Berlin, Germany). Elemental analysis for Co(II) was detected by an IRIS ER/S.WP-1 ICP atomic emission spectrometer (Berlin, Germany). ${ }^{1} \mathrm{H}$ NMR spectra were determined by a German Bruker AVANCE DRX-400 spectrometer (Bruker, Billerica, MA, USA). UV-vis titration was recorded on a Shimadzu UV-2550 spectrophotometer (Shimadzu, Kyoto, Japan) in mixed solvent $\left(\mathrm{DMF} / \mathrm{CH}_{3} \mathrm{OH}=1: 1, v / v\right)$. IR spectra were recorded on a Vertex 70 FT-IR spectrophotometer (Bruker, Billerica, MA, USA), with samples prepared as $\mathrm{KBr}\left(400-4000 \mathrm{~cm}^{-1}\right)$ pellets. X-ray single crystal structure was determined on a Agilent SuperNova Eos diffractometer (Bruker, Billerica, MA, USA). Melting points were measured by the use of a microscopic melting point apparatus made in Beijing Taike Instrument Limited Company (Beijing, China), and the thermometer was uncorrected. Fluorescence spectra were recorded on a Hitachi F-7000 FL spectrophotometer (Hitachi, Tokyo, Japan). Cyclic voltammetry measurements were performed using Chi 660 voltammetric analyzer (CH Instruments, Austin, TX, USA) in DMF containing $0.05 \mathrm{~mol} \mathrm{~L}^{-1}$ tetrabutylammonium perchlorate.

\subsection{Synthesis of $H_{4} L$}

1,2-Bis(aminooxy)ethane, 2-hydroxy-1-naphthaldehyde and 2,3-dihydroxynaphthalene-1, 4-dicarbaldehyde were synthesized according an analogous procedure reported earlier $[55,56]$. The major reaction steps of $\mathrm{H}_{4} \mathrm{~L}$ and its $\mathrm{Co}(\mathrm{II})$ complex are given in Scheme 1.
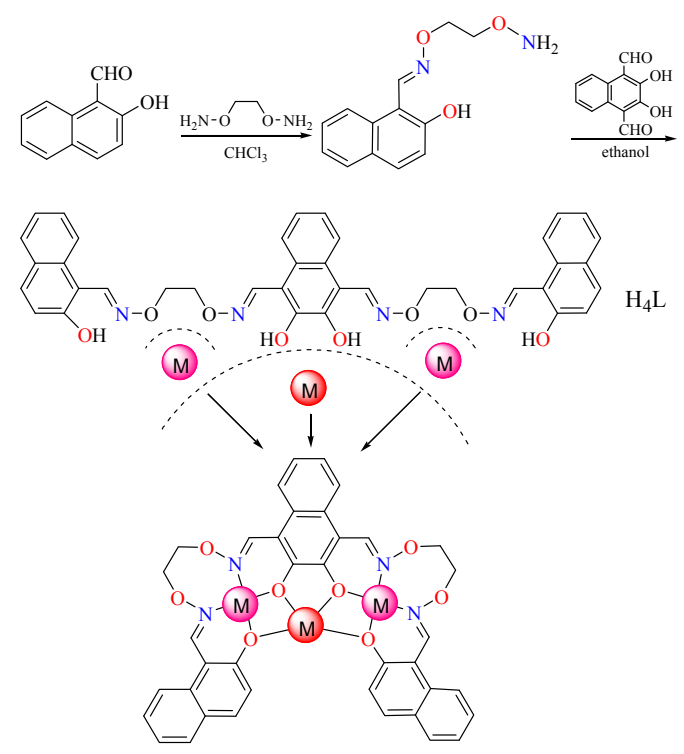

Scheme 1. Syntheses route to $\mathrm{H}_{4} \mathrm{~L}$ and its complex.

2,3-Dihydroxynaphthalene-1,4-dicarbaldehyde $(216.0 \mathrm{mg}, 1.0 \mathrm{mmol})$ was added to an ethanol solution (60 mL) of 2-[O-(1-ethyloxyamide)]oxime-2-naphthol (492.5 mg, $2 \mathrm{mmol})$. The suspension solution was stirred at $40^{\circ} \mathrm{C}$ for $15 \mathrm{~h}$. After cooling to room temperature, the precipitate was filtered and washed successively with ethanol and ethanol-hexane (1:4). The product was dried in vacuo, 
and $355.3 \mathrm{mg}$ of a yellow crystalline solid was obtained. Yield: $570.0 \mathrm{mg}(85.1 \%)$, m.p. $201-203{ }^{\circ} \mathrm{C}$. Anal. Calcd for $\mathrm{C}_{38} \mathrm{H}_{32} \mathrm{~N}_{4} \mathrm{O}_{8}(\%)$ : C, 67.85; $\mathrm{H}, 4.79 ; \mathrm{N}, 8.33$. Found: $\mathrm{C}, 67.83 ; \mathrm{H}, 4.80 ; \mathrm{N}, 8.36 .{ }^{1} \mathrm{H} \mathrm{NMR}$ $(400 \mathrm{MHz}, \mathrm{DMSO}) \delta 10.72(\mathrm{~s}, 4 \mathrm{H}), 9.14(\mathrm{~s}, 2 \mathrm{H}), 9.05(\mathrm{~s}, 2 \mathrm{H}), 8.67(\mathrm{~d}, J=8.5 \mathrm{~Hz}, 2 \mathrm{H}), 8.51(\mathrm{dd}, J=6.5$, $3.3 \mathrm{~Hz}, 2 \mathrm{H}), 7.85(\mathrm{dd}, J=15.7,8.4 \mathrm{~Hz}, 4 \mathrm{H}), 7.50(\mathrm{~s}, 2 \mathrm{H}), 7.36(\mathrm{~s}, 4 \mathrm{H}), 7.21(\mathrm{~d}, J=8.9 \mathrm{~Hz}, 2 \mathrm{H}), 4.62(\mathrm{~s}, 8 \mathrm{H})$.

\subsection{Synthesis of the Co(II) Complex}

A solution of cobalt(II) acetate tetrahydrate $(14.95 \mathrm{mg}, 0.06 \mathrm{mmol})$ in methanol $(3 \mathrm{~mL})$ was added dropwise to a solution of $\mathrm{H}_{4} \mathrm{~L}(13.44 \mathrm{mg}, 0.02 \mathrm{mmol})$ in chloroform $(4 \mathrm{~mL})$ at room temperature. After stirring for $20 \mathrm{~min}$, the color of the mixed solution turned to brown; the solvent was allowed to partially evaporate for two weeks at room temperature, after which nigger-brown block-shaped single crystals suitable for $\mathrm{X}$-ray diffraction studies were obtained. Anal. Calcd for $\mathrm{C}_{45} \mathrm{H}_{46} \mathrm{Co}_{3} \mathrm{~N}_{4} \mathrm{O}_{15}$ (\%): $\mathrm{C}, 51.00$; H, 4.38; N, 5.29; Co, 16.68. Found: C, 50.79; H, 4.33; N, 5.37; Co, 16.48 .

\subsection{Crystal Structure Determination of the Co(II) Complex}

Intensity data of the Co(II) complex was recorded at 293(2) K employing a Agilent SuperNova

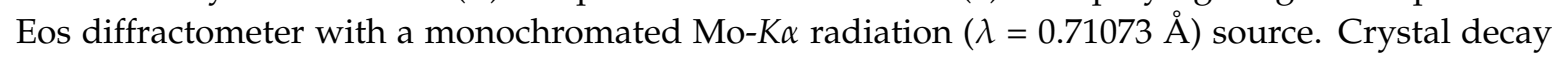
was not observed during the data collections. Multiscan absorption corrections were applied using the SADABS software (Bruker, Billerica, MA, USA). The structure was solved by using Fourier difference method and refined by the full-matrix least-squares method on $F^{2}$ using the SHELXTL [57] crystallographic software package (Bruker, Billerica, MA, USA). The non-hydrogen atoms were generated anisotropically. All hydrogen atoms were positioned geometrically. A summary of the crystal data and final details relevant to the structure determination is listed in Table 1.

Table 1. Crystal data and structure refinement parameters for the $\mathrm{Co}(\mathrm{II})$ complex.

\begin{tabular}{|c|c|}
\hline Formula & $\mathrm{C}_{45} \mathrm{H}_{46} \mathrm{Co}_{3} \mathrm{~N}_{4} \mathrm{O}_{15}$ \\
\hline Formula weight & 1059.65 \\
\hline Temperature (K) & 293(2) \\
\hline Wavelength $(\AA)$ & 0.71073 \\
\hline Crystal system & Monoclinic \\
\hline Space group & P 1 n 1 \\
\hline a $(\AA)$ & $8.9831(3)$ \\
\hline $\mathrm{b}(\AA)$ & $13.4177(4)$ \\
\hline$c(\AA)$ & $21.4815(7)$ \\
\hline$\alpha\left(^{\circ}\right)$ & 90.00 \\
\hline$\beta\left(^{\circ}\right)$ & $90.561(3)$ \\
\hline$\gamma\left(\left(^{\circ}\right)\right.$ & 90.00 \\
\hline$V\left(\AA^{3}\right)$ & $2589.10(15)$ \\
\hline $\mathrm{Z}, \mathrm{D}_{\mathrm{c}}\left(\mathrm{g} \mathrm{cm}^{-3}\right)$ & $2,1.359$ \\
\hline$\mu\left(\mathrm{mm}^{-1}\right)$ & 1.015 \\
\hline$\theta$ Range $\left(^{\circ}\right)$ & $3.336-24.999$ \\
\hline $\mathrm{F}(000)$ & 1090 \\
\hline Crystal size $(\mathrm{mm})$ & $0.14 \times 0.11 \times 0.04$ \\
\hline Index ranges & $\begin{array}{r}-10 \leq \mathrm{h} \leq 10 \\
-15 \leq \mathrm{k} \leq 15 \\
-18 \leq 1 \leq 25\end{array}$ \\
\hline Reflections collected/unique & $8775 / 5819\left[\mathrm{R}_{\mathrm{int}}=0.0350\right]$ \\
\hline $\begin{array}{c}\text { Completeness to } \theta=24.999 \\
\text { GOF }\end{array}$ & $\begin{array}{c}99.7 \% \\
0.982\end{array}$ \\
\hline Data/restraints/parameters & $5819 / 21 / 615$ \\
\hline Final $R_{1}, w R_{2}$ indices & $0.0362 / 0.0750$ \\
\hline$R_{1}, w R_{2}$ indices (all data) & $0.0405 / 0.0773$ \\
\hline Largest differences peak and hole $\left(\mathrm{e} \AA^{-3}\right)$ & $0.412 /-0.339$ \\
\hline
\end{tabular}




\section{Results and Discussion}

\subsection{IR Spectra}

The FT-IR spectra of the free ligand $\mathrm{H}_{4} \mathrm{~L}$ and its corresponding $\mathrm{Co}(\mathrm{II})$ complex are given in Figure 1. The ligand $\mathrm{H}_{4} \mathrm{~L}$ and its $\mathrm{Co}(\mathrm{II})$ complex show various bands in the region of $400-4000 \mathrm{~cm}^{-1}$. The ligand $\mathrm{H}_{4} \mathrm{~L}$ has a broad absorption band at $3419 \mathrm{~cm}^{-1}$, which is the stretching vibration absorption band of phenol hydroxyl group. The ligand $\mathrm{H}_{4} \mathrm{~L}$ shows a characteristic band of $\mathrm{C}=\mathrm{N}$ group at $1609 \mathrm{~cm}^{-1}$, which is shifted by $14 \mathrm{~cm}^{-1}$ in the Co(II) complex indicating that the Co(II) ions are coordinated by oxime nitrogen atoms of completely deprotonated (L) ${ }^{4-}$ units [58], which is similar to previously reported Co(II) complexes. The Ar-O stretching vibration of the ligand appears at $1235 \mathrm{~cm}^{-1}$ while the Co(II) complex is observed at $1231 \mathrm{~cm}^{-1}$ implying that the $\mathrm{Co}(\mathrm{II})$ ions are coordinated by oxygen atoms of phenolic groups of the $(\mathrm{L})^{4-}$ units [59]. In addition, a O-H stretching band can be found at $3411 \mathrm{~cm}^{-1}$ in the Co(II) complex, which indicates the presence of methanol molecules, which is in accordance with the results determined by X-ray diffraction.

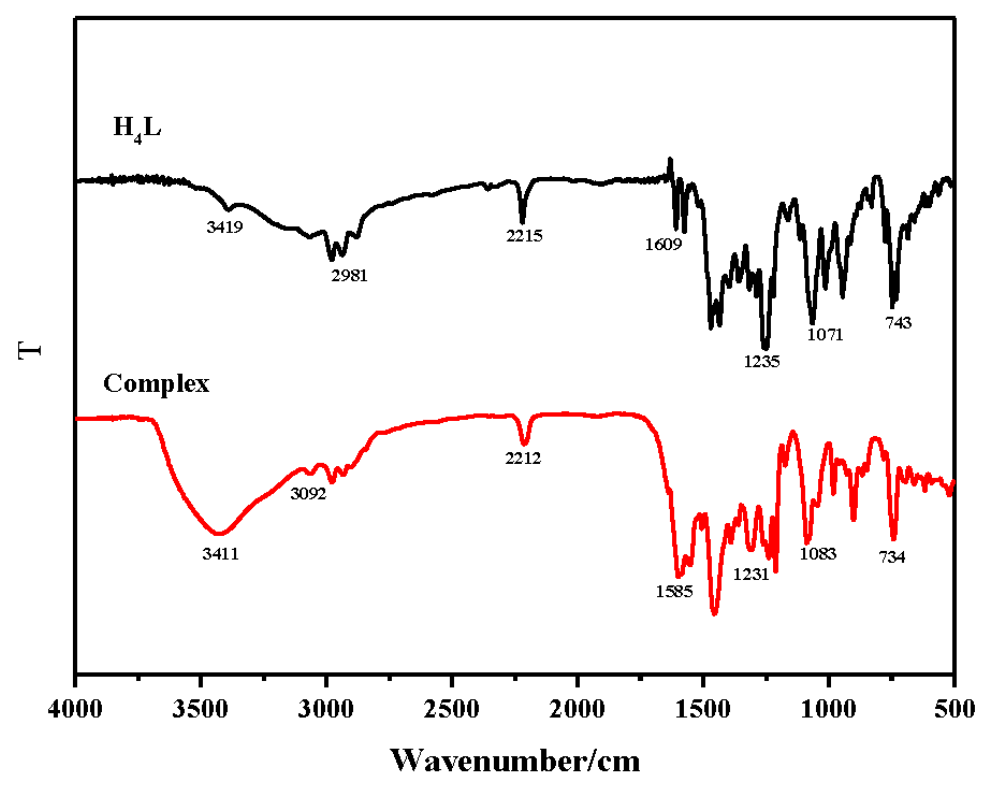

Figure 1. Infrared spectra of H4L and its Co(II) complex.

\subsection{UV-Vis Titration}

In the UV-vis titration experiment of the $\mathrm{Co}(\mathrm{II})$ complex, the solution of $\mathrm{H}_{4} \mathrm{~L}$ in mixed solvent $\left(\mathrm{DMF} / \mathrm{CH}_{3} \mathrm{OH}=1: 1, v / v\right)$ was changed from near colorless to light brown during the $\mathrm{Co}(\mathrm{II})$ acetate titration process. It can be seen from Figure 2 that the ligand $\mathrm{H}_{4} \mathrm{~L}$ has two strong absorption peaks at 313 and $355 \mathrm{~nm}$, which can be assigned to $\pi \rightarrow \pi^{*}$ type transition and indicates that the ligand $\mathrm{H}_{4} \mathrm{~L}$ contains a large conjugation system. The former can be assigned to the $\pi-\pi^{*}$ transition of the naphthalene rings and the latter one to the $\pi-\pi^{*}$ transition of the oxime groups [60]. Upon coordination of the ligand, the intraligand $\pi-\pi^{*}$ transition of the naphthalene rings of the salicylaldehyde group appears at ca. $317 \mathrm{~nm}$ in the $\mathrm{Co}(\mathrm{II})$ complex. Compared with the free ligand $\mathrm{H}_{4} \mathrm{~L}$, the absorption band at ca. $355 \mathrm{~nm}$ disappears from the UV-vis spectrum of the Co(II) complex, which indicates that the oxime nitrogen atoms are involved in coordination to the $\mathrm{Co}(\mathrm{II})$ atoms. Moreover, the new absorption band is observed at ca. $385 \mathrm{~nm}$ for the $\mathrm{Co}(\mathrm{II})$ complex, and assigned to $\mathrm{L} \rightarrow \mathrm{M}$ charge-transfer (LMCT) transition which is characteristic of the transition metal complexes with $\mathrm{N}_{2} \mathrm{O}_{2}$ coordination sphere [61].

The $\mathrm{H}_{4} \mathrm{~L}$ contains two salamo cavities and one $\mathrm{O}_{4}$ coordination environment and it is assumed that the coordination ratio of the $\mathrm{Co}$ (II) complex is 1:3. After the addition of 3.0 equiv of $\mathrm{Co}$ (II) acetate 
tetrahydrate, changes in UV-vis absorption intensity ceased. The result is consistent with the result of the elemental analyses mentioned above.
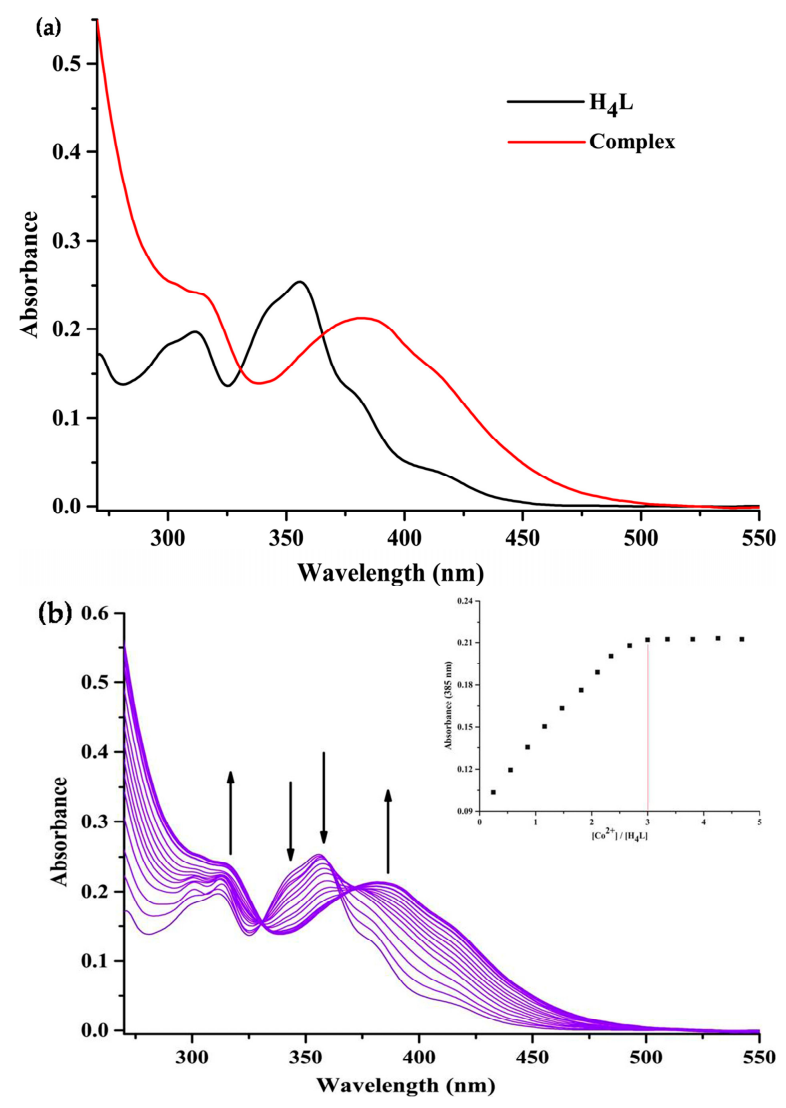

Figure 2. (a) UV-vis spectra of $\mathrm{H}_{4} \mathrm{~L}$ and corresponding Co(II) complex; (b) Absorption spectra of the Co(II) complex in the presence of different concentrations of $\mathrm{Co}(\mathrm{II})$ ion (0-3 equiv.) in (DMF/ $\left.\mathrm{CH}_{3} \mathrm{OH}=1: 1, v / v\right)$.

\subsection{Crystal Structure}

The analysis of the crystal structure of the $\mathrm{Co}$ (II) complex indicates that the $\mathrm{H}_{4} \mathrm{~L}$ to $\mathrm{Co}$ (II) ratio is 3:1. The molecule structure and coordination configuration of the Co(II) complex are illustrated in Figure 3. The parameter values of bond distances and angles are listed in Table 2.

Single-crystal X-ray diffraction analysis reveals that the Co(II) complex crystallizes in the monoclinic system in the $\mathrm{P} 1 \mathrm{n} 1$ space group with $\mathrm{Z}=2$. The $\mathrm{Co}$ (II) complex is composed of three $\mathrm{Co}$ (II) ions, one completely deprotonated $(\mathrm{L})^{4-}$ unit, two $\mu_{2}$-acetate ions, two methanol molecules participating in coordination and one uncoordinated methanol molecule. Three coordination environments of the $(\mathrm{L})^{4-}$ unit are occupied by three $\mathrm{Co}(\mathrm{II})$ atoms. From the coordination polyhedra of the $\mathrm{Co}(\mathrm{II})$ complex, it can be seen that the geometrical configuration of $\mathrm{Co} 1$ and $\mathrm{Co} 2$ atoms are different from the $\mathrm{Co} 3$ atom. The three $\mathrm{Co}$ (II) atoms were bridged by the two $\mu_{2}$-acetate groups. Terminal $\mathrm{Co} 3$ atom is penta-coordinated by two oxime nitrogen ( $\mathrm{N} 3$ and $\mathrm{N} 4)$ atoms, two deprotonated phenoxo-oxygen (O5 and O8) atoms of the (L) ${ }^{4-}$ unit and one oxygen (O11) atom of one $\mu_{2}$-acetate ion. The coordination geometry of $\mathrm{Co} 3$ atom is best described as a tetragonal pyramid coordination motif $(\tau=0.095)$ [62], as shown in Figure 3b. Co1 and $\mathrm{Co} 2$ atoms are hexa-coordinated with distorted octahedral geometries. The hexa-coordination of terminal Co1 atom is maintained by the $\mathrm{N}_{2} \mathrm{O}_{2}$ coordination sphere of the $(\mathrm{L})^{4-}$ unit and one oxygen $(\mathrm{O} 10)$ atom from the $\mu_{2}$-acetato bridge and another oxygen (O15) atom from the coordinated methanol molecule. While the central $\mathrm{Co}(\mathrm{II})(\mathrm{Co} 2)$ atom possesses three phenoxo-oxygen $(\mathrm{O} 1, \mathrm{O} 5$ and $\mathrm{O} 4)$ atoms from the $(\mathrm{L})^{4-}$ unit and double $\mu_{2}$-acetato oxygen (O9 and $\left.\mathrm{O} 12\right)$ atoms and another oxygen (O13) atom from the coordinated methanol molecule. It is worth noting that the two 
terminal $\mathrm{Co}$ (II) (Co1 and Co3) atoms of the Co(II) complex have different coordination modes and geometries, which isn't observed in the bis(salamo)-type complexes reported earlier [63].

Table 2. Selected bond lengths $(\AA)$ and angles $\left(^{\circ}\right)$ of the Co(II) complex.

\begin{tabular}{|c|c|c|c|}
\hline Bond & Lengths & Bond & Lengths \\
\hline Co1-O1 & $2.075(4)$ & Co2-O5 & $2.107(4)$ \\
\hline Co1-O4 & $2.029(4)$ & Co2-O9 & $2.086(4)$ \\
\hline Co1-O10 & $2.070(4)$ & Co2-O12 & $2.018(4)$ \\
\hline Co1-O15 & $2.143(4)$ & Co2-O13 & $2.142(5)$ \\
\hline Co1-N1 & $2.068(4)$ & Co3-O5 & $2.022(4)$ \\
\hline Co1-N2 & $2.155(4)$ & Co3-O8 & $1.950(4)$ \\
\hline $\mathrm{Co} 2-\mathrm{O} 1$ & $2.123(4)$ & Co3-O11 & $1.997(4)$ \\
\hline $\mathrm{Co} 2-\mathrm{O} 4$ & $2.066(4)$ & Co3-N3 & $2.042(4)$ \\
\hline Bond & Angles & Bond & Angles \\
\hline O1-Co1-O4 & $83.33(15)$ & O1-Co1-N1 & $85.63(16)$ \\
\hline O9-Co2-O13 & $175.45(16)$ & O5-Co3-O11 & $94.83(16)$ \\
\hline O1-Co1-O10 & $91.26(15)$ & O1-Co1-N2 & $165.68(16)$ \\
\hline O12-Co2-O13 & $90.19(18)$ & O5-Co3-N3 & 84.87(17) \\
\hline O1-Co1-O15 & $92.68(15)$ & O4-Co1-O10 & $89.68(15)$ \\
\hline O5-Co3-O8 & $91.62(15)$ & O5-Co3-N4 & $174.98(16$ \\
\hline O4-Co1-O15 & $90.20(15)$ & O10-Co1-O15 & $176.02(16)$ \\
\hline O8-Co3-O11 & 109.57(17) & O11-Co3-N3 & $123.21(18)$ \\
\hline O4-Co1-N1 & $168.95(16)$ & O10-Co1-N1 & 91.04(17) \\
\hline O8-Co3-N3 & $127.22(17)$ & O11-Co3-N4 & $90.18(17)$ \\
\hline O4-Co1-N2 & $82.36(15)$ & O10-Co1-N2 & $89.24(16)$ \\
\hline O8-Co3-N4 & $86.48(17)$ & N3-Co3-N4 & $92.58(17)$ \\
\hline O15-Co1-N1 & 89.84(17) & $\mathrm{O} 1-\mathrm{Co} 2-\mathrm{O} 4$ & $81.28(15)$ \\
\hline Co1-O1-Co2 & $93.70(16)$ & $\mathrm{O} 1-\mathrm{Co} 2-\mathrm{O} 5$ & $158.08(15)$ \\
\hline O15-Co1-N2 & $86.80(16)$ & N2-O3-C13 & 110.1(4) \\
\hline Co1-O1-C1 & $129.6(4)$ & O1-Co2-O9 & $89.69(15)$ \\
\hline N1-Co1-N2 & $108.68(16)$ & Co1-O4-Co2 & $96.82(17)$ \\
\hline $\mathrm{Co} 2-\mathrm{O} 1-\mathrm{C} 1$ & $136.5(4)$ & $\mathrm{O} 1-\mathrm{Co} 2-\mathrm{O} 12$ & $105.68(16)$ \\
\hline Co1-O4-C16 & $128.3(4)$ & Co2-O5-C17 & $111.6(3)$ \\
\hline $\mathrm{O} 1-\mathrm{Co} 2-\mathrm{O} 13$ & $94.82(16)$ & $\mathrm{O} 4-\mathrm{Co} 2-\mathrm{O} 12$ & $172.71(17)$ \\
\hline $\mathrm{Co} 2-\mathrm{O} 4-\mathrm{C} 16$ & 113.2(3) & Co3-O5-C17 & $128.5(3)$ \\
\hline $\mathrm{O} 4-\mathrm{Co} 2-\mathrm{O} 5$ & $76.85(15)$ & $\mathrm{O} 4-\mathrm{Co} 2-\mathrm{O} 13$ & $91.40(16)$ \\
\hline Co2-O5-Co3 & 119.50(18) & O5-Co2-O9 & $88.35(15)$ \\
\hline $\mathrm{O} 4-\mathrm{Co} 2-\mathrm{O} 9$ & $88.62(15)$ & O5-Co2-O12 & $96.12(15)$ \\
\hline Co3-O8-C29 & $133.6(3)$ & $\mathrm{Co} 2-\mathrm{O} 12-\mathrm{C} 40$ & $134.1(4)$ \\
\hline O5-Co2-O13 & $87.22(15)$ & Co2-O13-C42 & $128.4(4)$ \\
\hline Co2-O9-C38 & $129.2(3)$ & $\mathrm{Co} 2-\mathrm{O} 13-\mathrm{C} 1 \mathrm{~A}$ & 124.7(17) \\
\hline O9-Co2-O12 & $89.24(17)$ & Co1-O15-C44 & 135.1(4) \\
\hline Co1-O10-C38 & 128.7(4) & Co1-N1-O2 & $124.9(3)$ \\
\hline Co3-O11-C40 & 136.1(4) & Co1-N1-C11 & $126.7(4)$ \\
\hline Co1-N2-O3 & $126.3(3)$ & Co3-N3-O6 & 118.7(3) \\
\hline Co1-N2-C14 & $126.4(4)$ & Co3-N3-C24 & $126.5(4)$ \\
\hline Co1-O15-C44 & $135.5(4)$ & Co1-O15-H15 & $114(2)$ \\
\hline Co3-N4-O7 & $123.2(3)$ & Co2-O13-H13 & $116(3)$ \\
\hline Co3-N4-C27 & $127.6(4)$ & Co1-O15-H15 & $115(2)$ \\
\hline
\end{tabular}


(a)
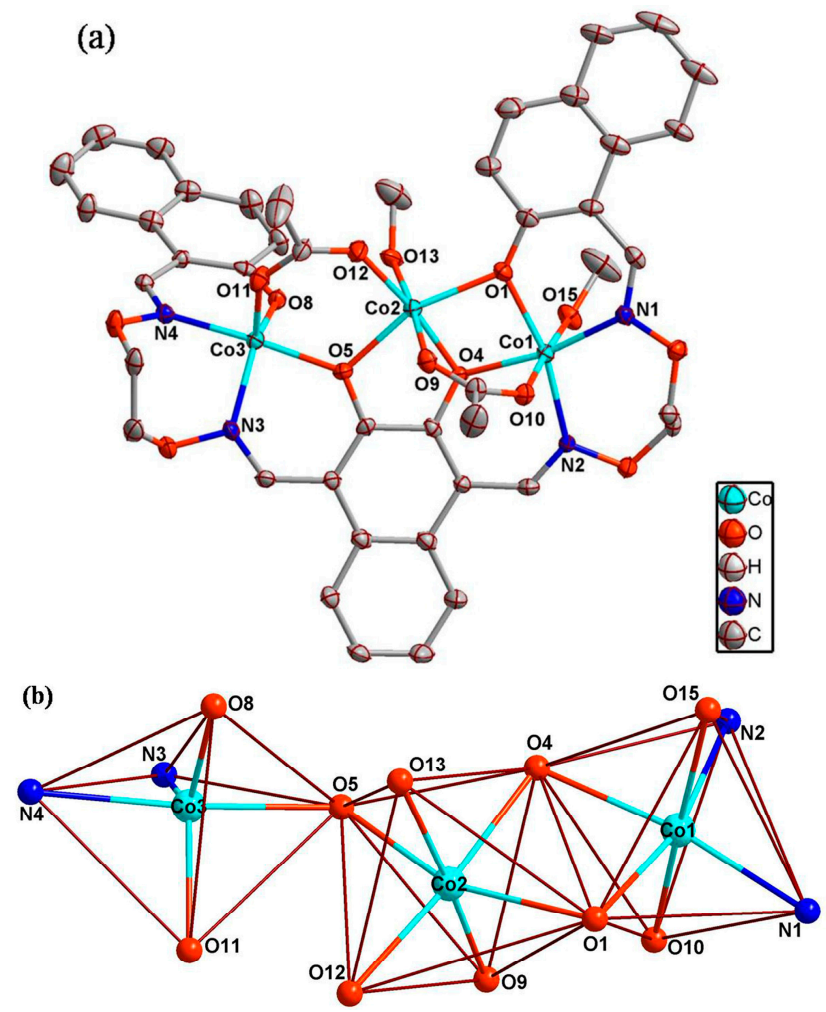

Figure 3. (a) Molecular structure and atom numbering of the Co(II) complex with $30 \%$ probability displacement ellipsoids (hydrogen atoms are omitted for clarity); (b) Coordination polyhedra for Co(II) ions.

The intramolecular and intermolecular hydrogen bonds are shown in Figures 4-6. The relevant values of the hydrogen bonds are listed in Table 3 [64]. With the help of intermolecular C-H..O , $\mathrm{C}-\mathrm{H} \cdots \pi$ and $\mathrm{O}-\mathrm{H} \cdots \mathrm{O}$ interactions [65], adjacent $\mathrm{Co}(\mathrm{II})$ complex moleculars can be linked into an infinite 2D layer-like network. Moreover, the Co(II) complex is stabilized further by two $\mathrm{C}-\mathrm{H} \cdots \pi$ weak hydrogen bonds [66-72] (Figure 4). The coordination entities are assembled via $\pi \cdots \pi$ stacking interactions (Cg...Cg distances in range 4.627(4)-4.860(4) $\AA$ ) to the supramolecular chain extending along crystallographic [010] axis [73].

Table 3. Hydrogen bonding interactions $\left(\AA \stackrel{\circ}{ }^{\circ}\right)$ of the complex.

\begin{tabular}{cccccc}
\hline & D-X & $\mathbf{X} \cdots \mathbf{A}$ & $\mathbf{D} \cdots \mathbf{A}$ & $\mathbf{D}-\mathbf{X} \cdots \mathbf{A}$ & Symmetry Codes \\
\hline C6-H6-O8 & 0.9300 & 2.5900 & $3.382(9)$ & 144.00 & $(x, 1+y, z)$ \\
C12-H12A-O10 & 0.9700 & 2.4500 & $3.292(7)$ & 145.00 & \\
C12-H12A-N2 & 0.9700 & 2.4700 & $2.871(7)$ & 105.00 & \\
C12-H12B-O11 & 0.9700 & 2.4700 & $3.400(8)$ & 160.00 & $(1 / 2+x, 1-y, 1 / 2+z)$ \\
C13-H13A-N1 & 0.9700 & 2.5500 & $2.919(7)$ & 102.00 & \\
C22-H22-O7 & 0.9300 & 2.5300 & $3.213(8)$ & 130.00 & $(1 / 2+x,-y, 1 / 2+z)$ \\
C26-H26B-O11 & 0.9700 & 2.4200 & $3.262(8)$ & 145.00 & \\
O13-H13-O8 & $0.87(2)$ & $1.94(3)$ & $2.723(6)$ & $149(5)$ & \\
O14-H14A-O9 & 0.8200 & 1.9100 & $2.715(6)$ & 168.00 & $(1+x, y, z)$ \\
O15-H15-O14 & $0.86(3)$ & $1.80(3)$ & $2.637(7)$ & $164(3)$ & \\
C13-H13B-Cg1 & & & 2.87 & & \\
C13-H13B-Cg2 & & & 2.99 & & \\
\hline
\end{tabular}

Symmetry codes: Cg1 and Cg2 for the Co(II) complex are the centroids of Co3, O8, N4, C27-C29 and C28-C32, C37 atoms, respectively. 


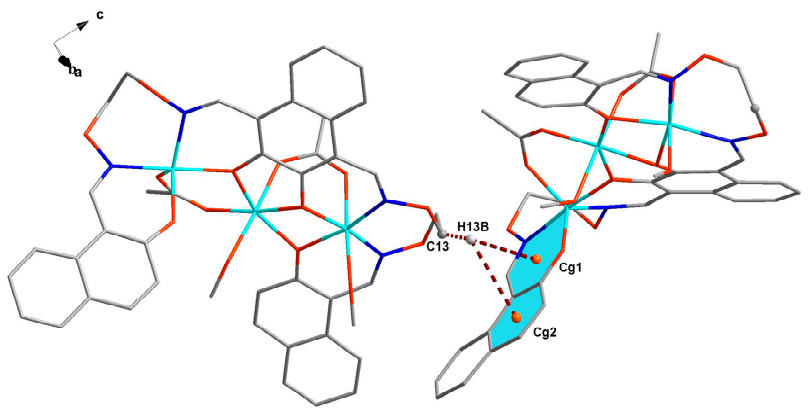

Figure 4. View of intermolecular $\mathrm{C}-\mathrm{H} \cdots \pi$ interactions of the $\mathrm{Co}(\mathrm{II})$ complex.

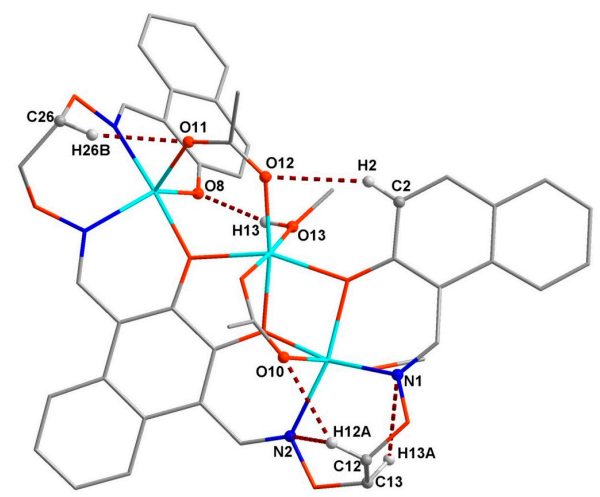

Figure 5. View of the intramolecular hydrogen-bonding interactions of the Co(II) complex.

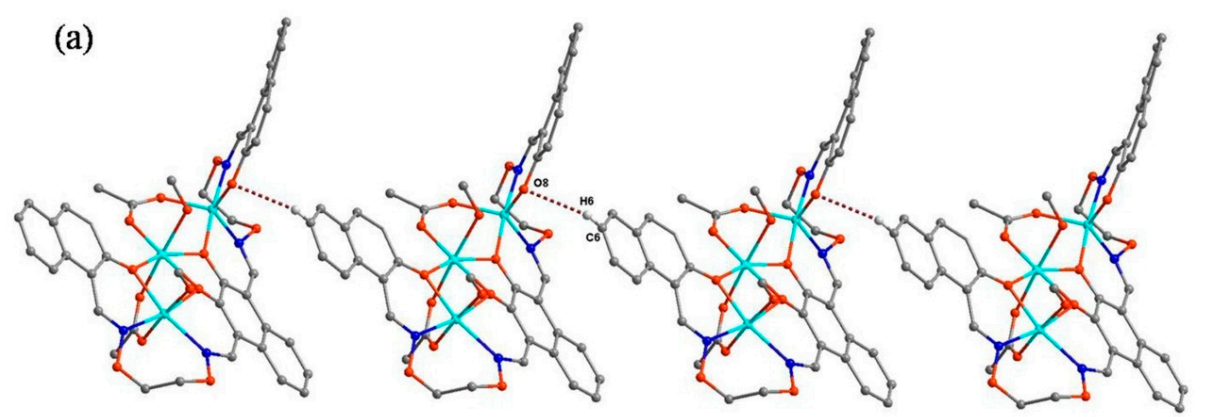

(b)

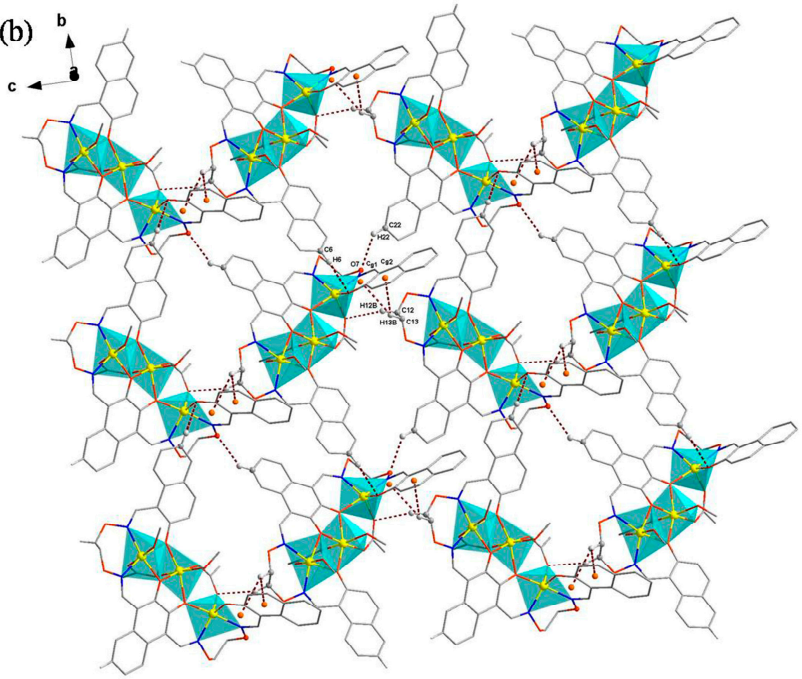

Figure 6. Cont. 


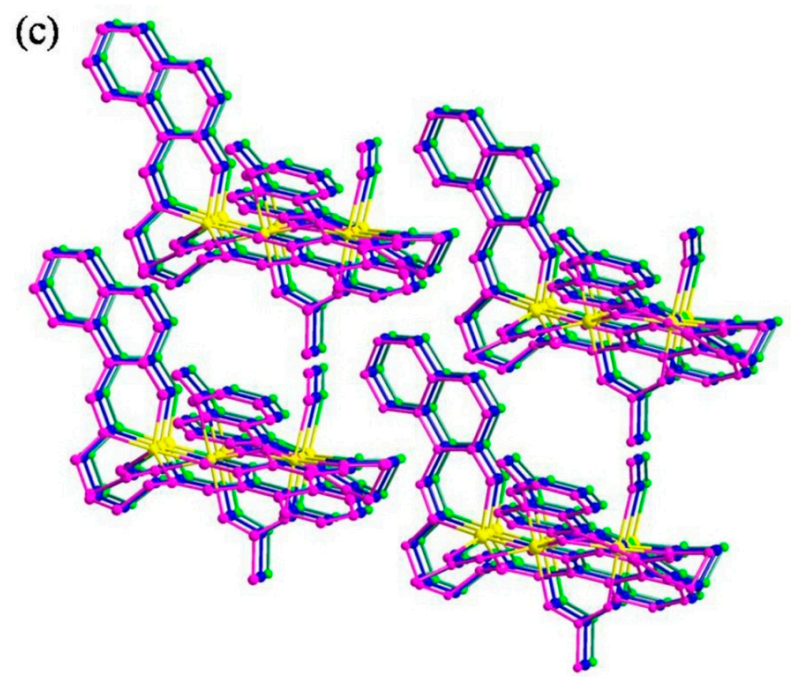

Figure 6. (a) View of the 1D chain structure of the Co(II) complex; (b) View of the 2D layer-like network of the Co(II) complex; (c) Packing diagram of the Co(II) complex.

\subsection{Fluorescence Properties}

The excitation and emission spectra of $\mathrm{H}_{4} \mathrm{~L}$ and its $\mathrm{Co}(\mathrm{II})$ complex in mixed solvent $\left(\mathrm{DMF} / \mathrm{CH}_{3} \mathrm{OH}=1: 1, v / v\right)$ at room temperature are shown in Figure 7 . The ligand shows an intense photoluminescence. The Co(II) complex shows a slightly weak photoluminescence, manifesting that fluorescent property has been influenced by the introduction of the $\mathrm{Co}(\mathrm{II})$ ions [74-76], which also give rise to the variation in IR and UV-vis spectra of the Co(II) complex.
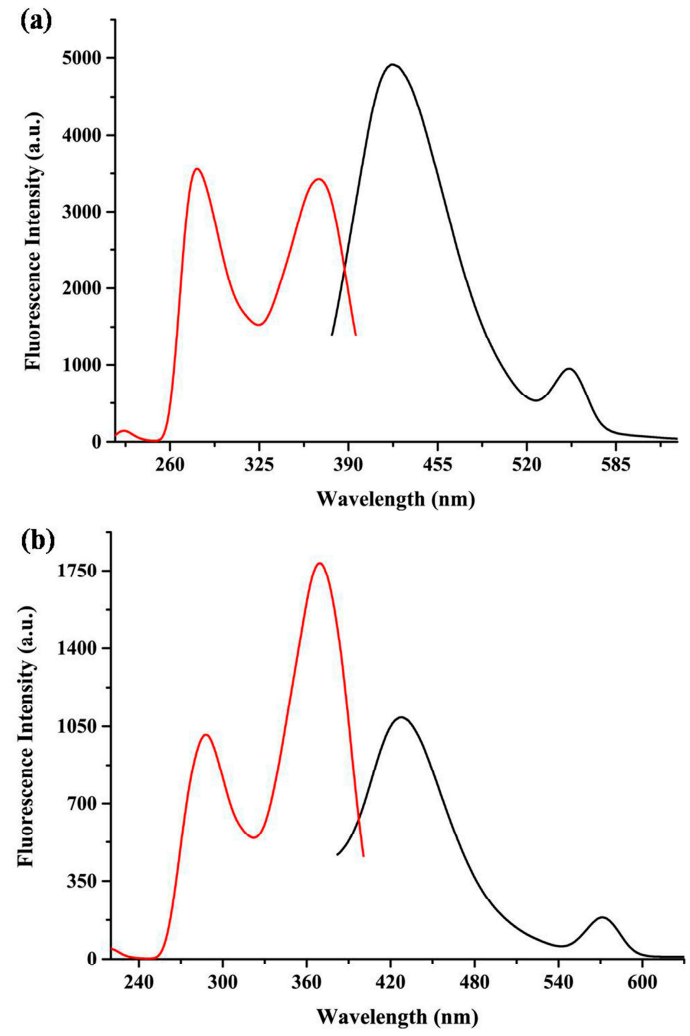

Figure 7. (a) The excitation and emission spectra of $\mathrm{H}_{4} \mathrm{~L}$; (b) The excitation and emission spectra of the Co(II) complex. 


\subsection{Antimicobial Activities}

Inhibitory bacterial experiments on commonly-used bacteria, namely E. coli and S. aureus, were performed using the punch method. A small amount $(0.1 \mathrm{~mL})$ of a fresh overnight bacterial suspension was added into autoclaved lysogeny broth (LB) agar, then the agar was poured into sterile dishes. The concentration of the test compounds were $0.625,1.25$ and $2.5 \mathrm{mg} / \mathrm{mL}$. $70 \mu \mathrm{L}$ of samples were added into a burrowed hole measuring $5 \mathrm{~mm}$ in diameter with transfer liquid gun when the medium underwent solidification. Ampicillin was used as a reference standard with different concentrations. After $6 \mathrm{~h}$ of incubation at $37^{\circ} \mathrm{C}$, the clear zones of inhibition were photographed.

The zones of DMF, complex, $\mathrm{H}_{4} \mathrm{~L}$ and cobalt acetate also had apparent differences in antibacterial activity among the two kinds of bacteria. The complex demonstrated more enhanced antimicrobial activities than the ligand under the same conditions $(2.5 \mathrm{mg} / \mathrm{mL})$ and the ligand has a weak biological activity; cobalt acetate also displayed little antimicrobial activity. Moreover, S. aureus exhibits stronger antibacterial activity, whereas E. coli has weaker antibacterial activity (Figure 8a,b). The diameter of inhibition zones of test compounds are illustrated in Figure 8c,d. As shown in Figure 8, this increase in the antibacterial activities of the $\mathrm{Co}$ (II) complex was accompanied with an increase in concentration.

(a)

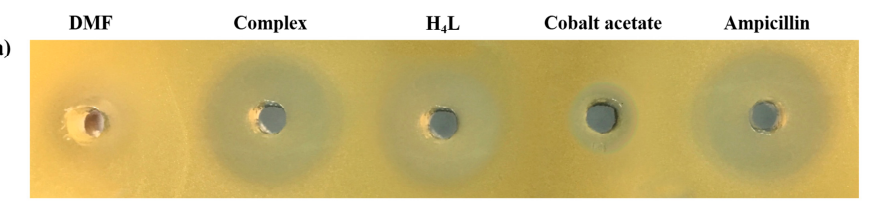

(b)
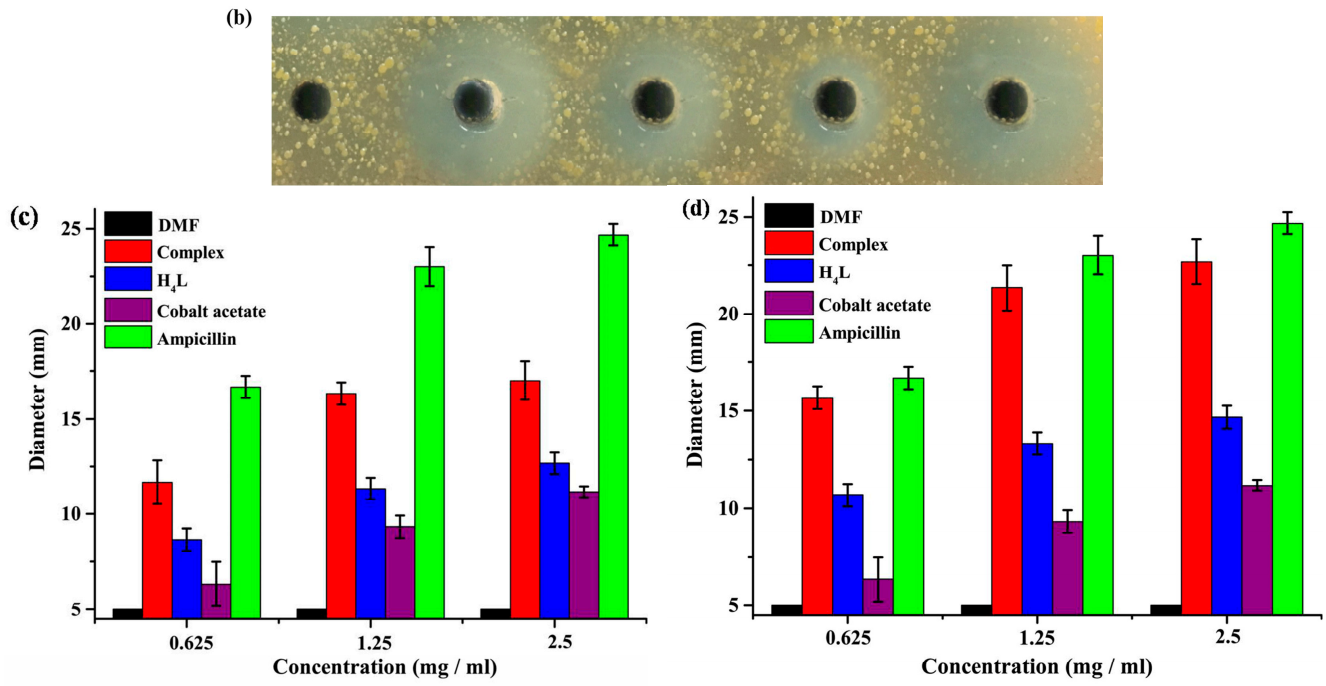

Figure 8. Inhibition of $\mathrm{H}_{4} \mathrm{~L}$ and its $\mathrm{Co}(\mathrm{II})$ complex on E. coli and S. aureus. (a,b) represent the inhibition effect of $\mathrm{H}_{4} \mathrm{~L}$ and its $\mathrm{Co}$ (II) complex on E. coli and S. aureus, respectively; (c) the diameter of inhibition zones of E. coli in different concentrations; (d) the diameter of inhibition zones of S. aureus in different concentrations)

\subsection{Electrochemistry Studies}

The voltammogram of the Co(II) complex is shown in Figure 9. The electrochemical measurement was carried out in a standard three-electrode cell, consisting of a glassy carbon (GC) disc ( $\mathrm{U}=5 \mathrm{~mm}$ ) as working electrode, a platinum wire as auxiliary and $\mathrm{Ag} / \mathrm{AgNO}_{3}$ as reference with the scanning rate of $50 \mathrm{mV} \mathrm{s}^{-1}$. There are two pairs of redox peaks during the electrolysis of the $\mathrm{Co}$ (II) complex resulting from the redox reaction of $\mathrm{Co}(\mathrm{III}) / \mathrm{Co}(\mathrm{II})$ and $\mathrm{Co}(\mathrm{II}) / \mathrm{Co}(\mathrm{I})$, respectively. The first pair of redox peaks are due to the electron transfer [77] between $\mathrm{Co}(\mathrm{III})$ and $\mathrm{Co}$ (II) during the electrolysis of the $\mathrm{Co}$ (II) complex with potential Epa $\mathrm{E}_{1}$ value of $-0.769 \mathrm{~V}$, Epc $\mathrm{C}_{1}$ value of $-0.865 \mathrm{~V}$ and current $\mathrm{iPa}_{1}=49.522 \mu \mathrm{A}, \mathrm{iPc}_{1}=-88.807 \mu \mathrm{A}$, the average potential $\mathrm{E}_{1 / 2}=-0.817 \mathrm{~V}$, the potential difference 
between oxidation peak and reduction peak were $0.096 \mathrm{~V}$ and current ratio were -0.557 . Another pair of redox peaks are because the electron transfer between $\mathrm{Co}(\mathrm{II})$ and $\mathrm{Co}(\mathrm{I})$ during the electrolysis of the $\mathrm{Co}(\mathrm{II})$ complex with potential Epa 2 value of $-0.865 \mathrm{~V}$, Epc $\mathrm{E}_{2}$ value of $-1.258 \mathrm{~V}$, current $\mathrm{iPa}_{2}=-3.340 \mu \mathrm{A}$, $\mathrm{iPc}_{1}=-90.056 \mu \mathrm{A}$ and the average potential $\mathrm{E}_{1 / 2}=-1.062 \mathrm{~V}$, the potential difference between oxidation peak and reduction peak were $0.393 \mathrm{~V}$ and current ratio were 0.0371 . In short, the experimental data reveal that electrolysis progress of the $\mathrm{Co}(\mathrm{II})$ complex is irreversible.

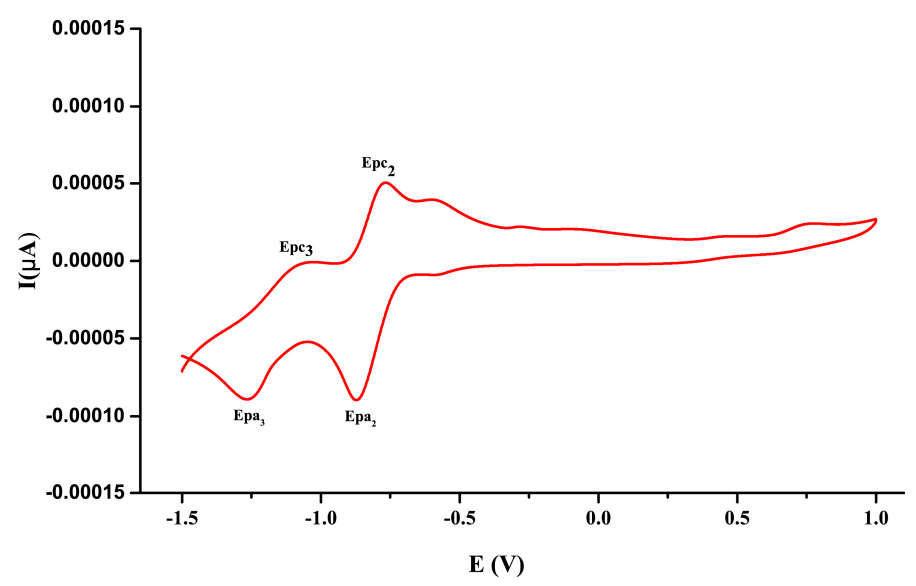

Figure 9. Cyclic voltammogram of the Co(II) complex in DMF at $298 \mathrm{~K}, \mathrm{c}=5 \times 10^{-4} \mathrm{M}$, scan rate $=50 \mathrm{mV} \mathrm{s}^{-1}$.

\section{Conclusions}

In this investigation, the Co(II) complex with a bis(salamo)-type ligand has been synthesized and characterized by IR, UV-vis spectra and X-ray crystallography. The Co(II) complex forms a 2D layer-like network by different intermolecular interactions. Hence, intermolecular non-classical hydrogen-bonding interactions play a key role in the construction of supramolecular frameworks. In addition, the luminance properties reveal that the Co(II) complex has a quality of fluorescent quenching. Furthermore, antimicrobial and electrochemical properties of $\mathrm{H}_{4} \mathrm{~L}$ and its $\mathrm{Co}$ (II) complex were also studied.

Acknowledgments: This work was supported by the National Natural Science Foundation of China (21361015, 21761018) and the Outstanding Research Platform (Team) of Lanzhou Jiaotong University, which are gratefully acknowledged.

Author Contributions: Wen-Kui Dong and Jing Hao conceived and designed the experiments; Li-Xiang Zhai performed the experiments; Yang Zhang analyzed the data; Li Wang wrote the paper.

Conflicts of Interest: The authors declare no conflict of interest.

\section{References}

1. Liu, Y.A.; Wang, C.Y.; Zhang, M.; Song, X.Q. Structures and magnetic properties of cyclic heterometallictetranuclear clusters. Polyhedron 2017, 127, 278-286. [CrossRef]

2. Dong, W.K.; Lan, P.F.; Zhou, W.M.; Zhang, Y. Salamo-type trinuclear and tetranuclear cobalt(II) complexes based on a new asymmetry salamo-type ligand: Syntheses, crystal structures and fluorescence properties. J. Coord. Chem. 2016, 65, 1272-1283. [CrossRef]

3. Dong, X.Y.; Akogun, S.F.; Zhou, W.M.; Dong, W.K. Tetranuclear Zn(II) complex based on an asymmetrical Salamo-type chelating ligand: Synthesis, structural characterization, and fluorescence property. J. Chin. Chem. Soc. 2017, 64, 412-419. [CrossRef]

4. Wu, H.L.; Pan, G.L.; Bai, Y.C.; Wang, H.; Kong, J.; Shi, F.R.; Zhang, Y.H.; Wang, X.L. Synthesis, structure, antioxidation, and DNA-binding studies of a binuclear ytterbium(III) complex with bis( $\mathrm{N}$-salicylidene)-3 -oxapentane-1,5-diamine. Res. Chem. Intermed. 2015, 41, 3375-3388. [CrossRef] 
5. Xu, L.; Zhu, L.C.; Ma, J.C.; Zhang, Y.; Zhang, J.; Dong, W.K. Syntheses, structures and spectral properties of mononuclear $\mathrm{Cu}^{\mathrm{II}}$ and dimeric $\mathrm{Zn}^{\mathrm{II}}$ complexes based on an asymmetric Salamo-type $\mathrm{N}_{2} \mathrm{O}_{2}$ ligand. Z. Anorg. Allg. Chem. 2015, 641, 2520-2524. [CrossRef]

6. Tao, C.H.; Ma, J.C.; Zhu, L.C.; Zhang, Y.; Dong, W.K. Heterobimetallic 3d-4f Zn(II)-Ln(III) (Ln = Sm, Eu, Tb and Dy) complexes with a $\mathrm{N}_{2} \mathrm{O}_{4}$ bisoxime chelate ligand and a simple auxiliary ligand Py: Syntheses, structures and luminescence properties. Polyhedron 2017, 128, 38-45. [CrossRef]

7. Dong, Y.J.; Dong, X.Y.; Dong, W.K.; Zhang, Y.; Zhang, L.S. Three asymmetric salamo-type copper(II) and cobalt(II) complexes: Syntheses, structures, fluorescent properties. Polyhedron 2017, 123, 305-315. [CrossRef]

8. Chai, L.Q.; Zhang, J.Y.; Chen, L.C.; Li, Y.X.; Tang, L.J. Synthesis, crystal structure, spectroscopic properties and DFT calculations of a new Schiff base-type zinc(II) complex. Res Chem. Intermed. 2016, 42, 3473-3488. [CrossRef]

9. Song, X.Q.; Peng, Y.J.; Chen, G.Q.; Wang, X.R.; Liu, P.P.; Xu, W.Y. Substituted group-directed assembly of $\mathrm{Zn}(\mathrm{II})$ coordination complexes based on two new structural related pyrazolone based salen ligands: Syntheses, structures and fluorescence properties. Inorg. Chim. Acta 2015, 427, 13-21. [CrossRef]

10. Dong, Y.J.; Ma, J.C.; Zhu, L.C.; Dong, W.K.; Zhang, Y. Four 3d-4f heteromultinuclear zinc(II)-lanthanide(III) complexes constructed from a distinct hexadentate $\mathrm{N}_{2} \mathrm{O}_{2}$-type ligand: Syntheses, structures and photophysical properties. J. Coord. Chem. 2017, 70, 103-115. [CrossRef]

11. Wang, L.; Ma, J.C.; Dong, W.K.; Zhu, L.C.; Zhang, Y. A novel Self-assembled nickel(II)-cerium(III) heterotetranuclear dimer constructed from $\mathrm{N}_{2} \mathrm{O}_{2}$-type bisoxime and terephthalic acid: Synthesis, structure and photophysical properties. Z. Anorg. Allg. Chem. 2016, 642, 834-839. [CrossRef]

12. Wu, H.L.; Wang, C.P.; Wang, F.; Peng, H.P.; Zhang, H.; Bai, Y.C. A new manganese(III) complex from bis(5-methylsalicylaldehyde)-3-oxapentane-1,5-diamine: Synthesis, characterization, antioxidant activity and luminescence. J. Chin. Chem. Soc. 2015, 62, 1028-1034. [CrossRef]

13. Chai, L.Q.; Huang, J.J.; Zhang, H.S. An unexpected cobalt (III) complex containing a schiff base ligand: Synthesis, crystal structure, spectroscopic behavior, electrochemical property and SOD-like activity. Spectrochim. Acta Part A 2014, 131, 526-530. [CrossRef] [PubMed]

14. Dong, W.K.; Li, X.L.; Wang, L.; Zhang, Y.; Ding, Y.J. A new application of salamo-type bisoximes: As a relay-sensor for $\mathrm{Zn}^{2+} / \mathrm{Cu}^{2+}$ and its novel complexes for successive sensing of $\mathrm{H}^{+} / \mathrm{OH}^{-}$. Sens. Actuators $B$ 2016, 229, 370-378. [CrossRef]

15. Song, X.Q.; Liu, P.P.; Xiao, Z.R.; Li, X.; Liu, Y.A. Four polynuclear complexes based on a versatile salicylamide salen-like ligand: Synthesis, structural variations and magnetic properties. Inorg. Chim. Acta 2015, 438, 232-244. [CrossRef]

16. Zheng, S.S.; Dong, W.K.; Zhang, Y.; Chen, L.; Ding, Y.J. Four Salamo-type 3d-4f hetero-bimetallic $\left[\mathrm{Zn}^{\mathrm{II}} \mathrm{Ln}^{\mathrm{III}}\right]$ complexes: Syntheses, crystal structures, and luminescent and magnetic properties. New J. Chem. 2017, 41, 4966-4973. [CrossRef]

17. Wang, B.J.; Dong, W.K.; Zhang, Y.; Akogun, S.F. A novel relay-sensor for highly sensitive and selective detection of $\mathrm{Zn}^{2+} / \mathrm{Pic}^{-}$and fluorescence on/off switch response of $\mathrm{H}^{+} / \mathrm{OH}^{-}$. Sens. Actuators B 2017, 247, 254-264. [CrossRef]

18. Dong, W.K.; Zhang, J.; Zhang, Y.; Li, N. Novel multinuclear transition metal(II) complexes based on an asymmetric salamo-type ligand: Syntheses, structure characterizations and fluorescent properties. Inorg. Chim. Acta 2016, 444, 95-102. [CrossRef]

19. Chai, L.Q.; Li, Y.X.; Chen, L.C.; Zhang, J.Y.; Huang, J.J. Synthesis, X-ray structure, spectroscopic, electrochemical properties and DFT calculation of a bridged dinuclear copper(II) complex. Inorg. Chim. Acta 2016, 444, 193-201. [CrossRef]

20. Chai, L.Q.; Zhang, K.Y.; Tang, L.J.; Zhang, J.Y.; Zhang, H.S. Two mono- and dinuclear ni(II) complexes constructed from quinazoline-type ligands: Synthesis, X-ray structures, spectroscopic, electrochemical, thermal, and antimicrobial studies. Polyhedron 2017, 130, 100-107. [CrossRef]

21. Chai, L.Q.; Tang, L.J.; Chen, L.C.; Huang, J.J. Structural, spectral, electrochemical and DFT studies of two mononuclear manganese(II) and zinc(II) complexes. Polyhedron 2017, 122, 228-240. [CrossRef]

22. Chai, L.Q.; Huang, J.J.; Zhang, J.Y.; Li, Y.X. Two 1-D and 2-D cobalt(II) complexes: Synthesis, crystal structures, spectroscopic and electrochemical properties. J. Coord. Chem. 2015, 68, 1224-1237. [CrossRef] 
23. Dong, Y.J.; Li, X.L.; Zhang, Y.; Dong, W.K. A highly selective visual and fluorescent sensor for $\mathrm{Pb}^{2+}$ and $\mathrm{Zn}^{2+}$ and crystal structure of $\mathrm{Cu}^{2+}$ complex based-on a novel single-armed salamo-type bisoxime. Supramol. Chem. 2017, 29, 518-527. [CrossRef]

24. Pu, L.M.; Akogun, S.F.; Li, X.L.; Long, H.T.; Dong, W.K.; Zhang, Y. A salamo-type fluorescent sensor for selective detection of $\mathrm{Zn}^{2+} / \mathrm{Cu}^{2+}$ and its novel $\mathrm{Cd}^{2+}$ complex with triangular prism geometry. Polyhedron 2017, 134, 356-364. [CrossRef]

25. Dong, W.K.; Akogun, S.F.; Zhang, Y.; Sun, Y.X.; Dong, X.Y. A reversible “turn-on” fluorescent sensor for selective detection of $\mathrm{Zn}^{2+}$. Sens. Actuators B 2017, 238, 723-734. [CrossRef]

26. Liu, P.P.; Wang, C.Y.; Zhang, M.; Song, X.Q. Pentanuclear sandwich-type Zn ${ }^{\mathrm{II}}-\mathrm{Ln}^{\mathrm{III}}$ clusters based on a new salen-like salicylamide ligand: Structure, near-infrared emission and magnetic properties. Polyhedron 2017, 129, 133-140. [CrossRef]

27. Chen, L.; Dong, W.K.; Zhang, H.; Zhang, Y.; Sun, Y.X. Structural variation and luminescence properties of triand dinuclear $\mathrm{Cu}^{\mathrm{II}}$ and $\mathrm{Zn}^{\mathrm{II}}$ complexes constructed from a naphthalenediol-based bis(Salamo)-type ligand. Cryst. Growth Des. 2017, 17, 3636-3648. [CrossRef]

28. Liu, P.P.; Sheng, L.; Song, X.Q.; Xu, W.Y.; Liu, Y.A. Synthesis, structure and magnetic properties of a new one dimensional manganese coordination polymer constructed by a new asymmetrical ligand. Inorg. Chim. Acta 2015, 434, 252-257. [CrossRef]

29. Dong, W.K.; Ma, J.C.; Zhu, L.C.; Sun, Y.X.; Zhang, Y. A series of heteromultinuclear zinc(II)-lanthanide(III) complexes based on 3-MeOsalamo: Syntheses, structural characterizations, and luminescent properties. Cryst. Growth Des. 2016, 16, 6903-6914. [CrossRef]

30. Dong, W.K.; Zhang, F.; Li, N.; Xu, L.; Zhang, Y.; Zhang, J.; Zhu, L.C. Trinuclear cobalt(II) and zinc(II) salamo-type complexes: Syntheses, crystal structures, and fluorescent properties. Z. Anorg. Allg. Chem. 2016, 642, 532-538. [CrossRef]

31. Dong, W.K.; Sun, Y.X.; Zhao, C.Y.; Dong, X.Y.; Xu, L. Synthesis, structure and properties of supramolecular $\mathrm{Mn}^{\mathrm{II}}, \mathrm{Co}^{\mathrm{II}}, \mathrm{Ni}^{\mathrm{II}}$ and $\mathrm{Zn}^{\mathrm{II}}$ complexes containing salen-type bisoxime ligands. Polyhedron 2010, 29, $2087-2097$. [CrossRef]

32. Dong, W.K.; Du, W.; Zhang, X.Y.; Li, G.; Dong, X.Y. Synthesis, crystal structure and spectral properties of a supramolecular trinuclear nickel(II) complex with 5-methoxy-4'-bromo-2,2'-[ethylenedioxybis (nitrilomethylidyne)]diphenol. Spectrochim. Acta Part A 2014, 132, 588-593. [CrossRef] [PubMed]

33. Dong, W.K.; Zhu, L.C.; Dong, Y.J.; Ma, J.C.; Zhang, Y. Mono, di and heptanuclear metal(II) complexes based on symmetric and asymmetric tetradentate salamo-type ligands: Syntheses, structures and spectroscopic properties. Polyhedron 2016, 117, 148-154. [CrossRef]

34. Dong, W.K.; Zhang, X.Y.; Sun, Y.X.; Dong, X.Y.; Li, G.; Wang, J. A 2D supramolecular copper(II) complex with an asymmetric salamo-type ligand: Synthsis, crystal structure, and fluorescent property. Synth. React. Inorg. Met.-Org. Nano-Met Chem. 2015, 45, 956-962. [CrossRef]

35. Wang, P.; Zhao, L. Synthesis and crystal structure of supramolecular copper(II) complex based on $\mathrm{N}_{2} \mathrm{O}_{2}$ coordination sphere. Asian J. Chem. 2015, 4, 1424-1426. [CrossRef]

36. Sun, Y.X.; Sun, W.Y. Zinc(II)- and cadmium(II)-organic frameworks with 1-imidazole-containing and 1-imidazole-carboxylate Liands. Cryst. Eng. Commun. 2015, 17, 4045-4063. [CrossRef]

37. Dong, W.K.; Wang, G.; Gong, S.S.; Tong, J.F.; Sun, Y.X.; Gao, X.H. Synthesis, structural characterization and substituent effects of two copper(II) complexes with benzaldehyde ortho-oxime ligands. Transit. Met. Chem. 2012, 37, 271-277. [CrossRef]

38. Wu, H.L.; Bai, Y.C.; Zhang, Y.H.; Pan, G.L.; Kong, J.; Shi, F.; Wang, X.L. Two lanthanide(III) complexes based on the schiff base $N, N$-Bis(salicylidene)-1,5-diamino-3-oxapentane: Synthesis, characterization, DNA-binding properties, and antioxidation. Z. Anorg. Allg. Chem. 2014, 640, 2062-2071. [CrossRef]

39. Chen, C.Y.; Zhang, J.W.; Zhang, Y.H.; Yang, Z.H.; Wu, H.L.; Pana, G.L.; Bai, Y.C. Gadolinium(III) and dysprosium(III) complexes with a schiff base bis( $N$-salicylidene)-3-oxapentane-1,5-diamine: Synthesis, characterization, antioxidation, and DNA-binding studies. J. Coord. Chem. 2015, 68, 1054-1071. [CrossRef]

40. Wu, H.L.; Bai, Y.; Yuan, J.K.; Wang, H.; Pan, G.L.; Fan, X.Y.; Kong, J. A zinc(II) complex with tris(2-(N-methyl)benzimidazlylmethyl)amine and salicylate: Synthesis, crystal structure, and DNA-binding. J. Coord. Chem. 2012, 65, 2839-2851. [CrossRef]

41. Wu, H.L.; Pan, G.L.; Wang, H.; Wang, X.L.; Bai, Y.C.; Zhang, Y.H. Study on synthesis, crystal structure, antioxidant and DNA-binding of mono-, di- and poly-nuclear lanthanides complexes with 
bis(N-salicylidene)-3-oxapentane-1,5-diamine. J. Photochem. Photobiol. B Biol. 2014, 135, 33-43. [CrossRef] [PubMed]

42. Wu, H.L.; Bai, Y.C.; Zhang, Y.H.; Li, Z.; Wu, M.C.; Chen, C.Y.; Zhang, J.W. Synthesis, crystal structure, antioxidation and DNA-binding properties of a dinuclear copper(II) complex with bis(N-salicylidene)-3 -oxapentane-1,5-diamine. J. Coord. Chem. 2014, 67, 3054-3066. [CrossRef]

43. Dong, W.K.; Zhu, L.C.; Ma, J.C.; Sun, Y.X.; Zhang, Y. Two novel mono-and heptanuclear ni(II) complexes constructed from new unsymmetric and symmetric salamo-type bisoximes-synthetic, structural and spectral studies. Inorg. Chim. Acta 2016, 453, 402-408. [CrossRef]

44. Dong, W.K.; Ma, J.C.; Zhu, L.C.; Zhang, Y.; Li, X.L. Four new nickel(II) complexes based on an asymmetric salamo-type ligand: Synthesis, structure, solvent effect and electrochemical property. Inorg. Chim. Acta 2016, 445, 140-148. [CrossRef]

45. Dong, W.K.; Ma, J.C.; Dong, Y.J.; Zhu, L.C.; Zhang, Y. Di-and tetranuclear heterometallic 3d-4f cobalt(II)-lanthanide(III) complexes derived from a hexadentate bisoxime: Syntheses, structures and magnetic properties. Polyhedron 2016, 115, 228-235. [CrossRef]

46. Dong, W.K.; Ma, J.C.; Zhu, L.C.; Zhang, Y. Nine self-assembled nickel(II)-lanthanide(III) heterometallic complexes constructed from a salamo-type bisoxime and bearing a $\mathrm{N}$ - or O-donor auxiliary ligand: Syntheses, structures and magnetic properties. New J. Chem. 2016, 40, 6998-7010. [CrossRef]

47. Akine, S.; Taniguchi, T.; Nabeshima, T. Novel synthetic approach to trinuclear 3d-4f complexes: Specific exchange of the central metal of a trinuclear Zinc(II) complex of a tetraoxime ligand with a lanthanide(III) ion. Angew. Chem. Int. Ed. 2002, 41, 4670-4673. [CrossRef] [PubMed]

48. Sun, Y.X.; Gao, X.H. Synthesis, characterization, and crystal structure of a new Cu ${ }^{\mathrm{II}}$ complex with salen-type ligand. Synth. React. Inorg. Met-Org. Nano-Met. Chem. 2011, 41, 973-978. [CrossRef]

49. Hao, J.; Li, L.H.; Zhang, J.T.; Akogun, S.F.; Wang, L.; Dong, W.K. Four homo- and hetero-bismetallic 3d/3d-2s complexes constructed from a naphthalenediol-based acyclic bis(salamo)-type tetraoxime ligand. Polyhedron 2017, 134, 1-10. [CrossRef]

50. Zhao, L.; Dong, X.T.; Chen, Q.; Zhao, J.X.; Wang, L. Synthesis, crystal structure and spectral properties of a 2D supramolecular copper(II) complex with 1-(4-\{[(E)-3-ethoxyl-2-hydroxybenzylidene] amino\} phenyl) ethanone oxime. Synth. React. Inorg. Met-Org. Nano-Met. Chem. 2013, 43, 1241-1246. [CrossRef]

51. Wang, P.; Zhao, L. An infinite 2D supramolecular cobalt(II) complex based on an asymmetric salamo-type ligand: Synthesis, crystal structure, and spectral properties. Synth. React. Inorg. Met-Org. Nano-Met. Chem. 2016, 46, 1095-1101. [CrossRef]

52. Sun, Y.X.; Wang, L.; Dong, X.Y.; Ren, Z.L.; Meng, W.S. Synthesis, characterization, and crystal structure of a supramolecular $\mathrm{Co}^{\mathrm{II}}$ complex containing salen-type bisoxime. Synth. React. Inorg. Met-Org. Nano-Met. Chem. 2013, 43, 599-603. [CrossRef]

53. Wang, P.; Zhao, L. Synthesis, structure and spectroscopic properties of the trinuclear cobalt(II) and nickel(II) complexes based on 2-hydroxynaphthaldehyde and bis(aminooxy) alkane. Spectrochim. Acta Part A 2015, 135, 342-350. [CrossRef] [PubMed]

54. Dong, W.K.; Li, G.; Li, X.; Yang, C.J.; Zhao, M.M.; Dong, X.Y. An asymmetrical salamo-type chelating ligand with its cobalt(II) complex: Syntheses, characterizations and crystal structures. Chin. J. Inorg. Chem. 2014, 30, 1911-1919.

55. Dong, X.Y.; Gao, L.; Wang, F.; Zhang, Y.; Dong, W.K. Tri- and Mono-Nuclear Zinc(II) Complexes Based on Half- and Mono-Salamo Chelating Ligands. Crystals 2017, 7, 267. [CrossRef]

56. Dong, W.K.; Zhang, J.T.; Dong, Y.J.; Zhang, Y.; Wang, Z.K. Construction of mononuclear copper(II) and trinuclear cobalt(II) complexes based on asymmetric Salamo-Type ligands. Z. Anorg. Allg. Chem. 2016, 642, 189-196. [CrossRef]

57. Sheldrick, G.M. SHELXS-97, Program for the Solution and the Refinement of Crystal Structures; University of Gottingen: Gottingen, Germany, 1997.

58. Chai, L.Q.; Wang, G.; Sun, Y.X.; Dong, W.K.; Zhao, L.; Gao, X.H. Synthesis, crystal structure, and fluorescence of an unexpected dialkoxo-bridged dinuclear copper(II) complex with bis(salen)-type tetraoxime. J. Coord. Chem. 2012, 65, 1621-1631. [CrossRef]

59. Dong, W.K.; He, X.N.; Yan, H.B.; Lu, Z.W.; Chen, X.; Zhao, C.Y.; Tang, X.L. Synthesis, structural characterization and solvent effect of copper(II) complexes with a variational multidentate salen-type ligand with bisoxime groups. Polyhedron 2009, 28, 1419-1428. [CrossRef] 
60. Li, G.; Hao, J.; Liu, L.Z.; Zhou, W.M.; Dong, W.K. Syntheses, crystal structures and thermal behaviors of two supramolecular salamo-type cobalt(II) and zinc(II) complexes. Crystals 2017, 7, 217.

61. Jia, H.R.; Li, J.; Sun, Y.X.; Guo, J.Q.; Yu, B.; Wen, N.; Xu, L. Two supramolecular cobalt(II) complexes: Syntheses, crystal structures, spectroscopic behaviors, and counter anion effects. Crystals 2017, 7, 247.

62. Dong, W.K.; Li, G.; Wang, Z.K.; Dong, X.Y. A novel trinuclear cobalt(II) complex derived from an asymmetric Salamo-type $\mathrm{N}_{2} \mathrm{O}_{3}$ bisoxime chelate ligand: Synthesis, structure and optical properties. Spectrochim. Acta Part A 2014, 133, 340-347. [CrossRef] [PubMed]

63. Li, L.H.; Dong, W.K.; Zhang, Y.; Akogun, S.F.; Xu, L. Syntheses, structures and catecholase activities of homo- and hetero-trinuclear cobalt (II) complexes constructed from an acyclic naphthalenediol-based bis (Salamo)-type ligand. Appl. Organomet. Chem. 2017, e3818. [CrossRef]

64. Bernstein, J.; Davis, R.E.; Shimoni, L.; Chang, N.L. Patterns in hydrogen bonding: Functionality and graph set analysis in crystals. Angew. Chem. Int. Ed. Engl. 1995, 34, 1555-1573. [CrossRef]

65. Chai, L.Q.; Liu, G.; Zhang, Y.L.; Huang, J.J.; Tong, J.F. Synthesis, crystal structure, fluorescence, electrochemical property, and SOD-like activity of an unexpected nickel(II) complex with a quinazoline-type ligand. J. Coord. Chem. 2013, 66, 3926-3938. [CrossRef]

66. Song, X.Q.; Cheng, G.Q.; Liu, Y.A. Enhanced $\mathrm{Tb}(\mathrm{III})$ luminescence by $\mathrm{d}^{1 \circ}$ transition metal coordination. Inorg. Chim. Acta 2016, 450, 386-394. [CrossRef]

67. Hao, J.; Liu, L.Z.; Dong, W.K.; Zhang, J.; Zhang, Y. Three multinuclear Co(II), Zn(II) and Cd(II) complexes based on a single-armed salamo-type bisoxime: Syntheses, structural characterizations and fluorescent properties. J. Coord. Chem. 2017, 70, 1936-1952. [CrossRef]

68. Zhang, H.; Dong, W.K.; Zhang, Y.; Akogun, S.F. Naphthalenediol-based bis(Salamo)-type homo- and heterotrinuclear cobalt(II) complexes: Syntheses, structures and magnetic properties. Polyhedron 2017, 133, 279-293. [CrossRef]

69. Dong, W.K.; Zheng, S.S.; Zhang, J.T.; Zhang, Y.; Sun, Y.X. Luminescent properties of heterotrinuclear 3d-4f complexes constructed from a naphthalenediol-based acyclic bis(salamo)-type ligand. Spectrochim. Acta Part A 2017, 184, 141-150. [CrossRef] [PubMed]

70. Sun, Y.X.; Zhao, Y.Y.; Li, C.Y.; Yu, B.; Guo, J.Q.; Li, J. Supramolecular Cobalt(II) and Copper(II) complexes with Schiff base ligand: Syntheses, characterizations and crystal structures. Chin. J. Inorg. Chem. 2016, 32, 913-920.

71. Dong, W.K.; Sun, Y.X.; Zhang, Y.P.; Li, L.; He, X.N.; Tang, X.L. Synthesis, crystal structure, and properties of supramolecular $\mathrm{Cu}^{\mathrm{II}}, \mathrm{Zn}^{\mathrm{II}}$, and $\mathrm{Cd}^{\mathrm{II}}$ complexes with Salen-type bisoxime ligands. Inorg. Chim. Acta 2009, 362, 117-124. [CrossRef]

72. Sun, Y.X.; Yang, C.J.; Zhao, Y.Y.; Guo, J.Q. Two Cu(II) complexes with Schiff base ligands: Syntheses, crystal structures, spectroscopic properties. Chin. J. Inorg. Chem. 2016, 32, 327-335.

73. Kruszynski, R.; Sierański, T. Can stacking interactions exist beyond the commonly accepted limits? Cryst. Growth Des. 2016, 16, 587-595. [CrossRef]

74. Dong, W.K.; Li, X.; Yang, C.J.; Zhao, M.M.; Li, G.; Dong, X.Y. Syntheses and crystal structures of 5-Methoxy-6'-hydroxy-2,2' [ethylenedioxybis(nitrilomethylidyne)]diphenol and its tetranuclear zinc(II) complex. Chin. J. Inorg. Chem. 2014, 30, 710-716.

75. Dong, W.K.; Duan, J.G.; Guan, Y.H.; Shi, J.Y.; Zhao, C.Y. Synthesis, crystal structure and spectroscopic behaviors of $\mathrm{Co}(\mathrm{II})$ and $\mathrm{Cu}(\mathrm{II})$ complexes with Salen-type bisoxime ligands. Inorg. Chim. Acta 2009, 362, 1129-1134. [CrossRef]

76. Song, X.Q.; Liu, P.P.; Liu, Y.A.; Zhou, J.J.; Wang, X.L. Two dodecanuclear heterometallic $\left[\mathrm{Zn}_{6} \operatorname{Ln}_{6}\right]$ clusters constructed by a multidentate salicylamide salen-like ligand: Synthesis, structure, luminescence and magnetic properties. Dalton Trans. 2016, 45, 8154-8163. [CrossRef] [PubMed]

77. Chai, L.Q.; Mao, K.H.; Zhang, J.Y.; Zhang, K.Y.; Zhang, H.S. Synthesis, X-ray crystal structure, spectroscopic, electrochemical and antimicrobial studies of a new dinuclear cobalt(III) complex. Inorg. Chim. Acta 2017, 457, 34-40. [CrossRef]

(C) 2017 by the authors. Licensee MDPI, Basel, Switzerland. This article is an open access article distributed under the terms and conditions of the Creative Commons Attribution (CC BY) license (http://creativecommons.org/licenses/by/4.0/). 